Social Sciences on Contemporary Turkey

19 | 2014

Heritage Production in Turkey. Actors, Issues, and

Scales - Part I

Whose Tradition, Whose Identity? The politics of constructing "Nevruz" as intangible heritage in Turkey

Bahar Aykan

CpenEdition

Journals

Electronic version

URL: http://journals.openedition.org/ejts/5000

DOI: $10.4000 /$ ejts.5000

ISSN: $1773-0546$

Publisher

EJTS

Electronic reference

Bahar Aykan, "Whose Tradition, Whose Identity? The politics of constructing "Nevruz" as intangible heritage in Turkey », European Journal of Turkish Studies [Online], 19 | 2014, Online since 11 December 2014, connection on 16 February 2020. URL : http://journals.openedition.org/ejts/5000 ; DOI : $10.4000 /$ ejts.5000

This text was automatically generated on 16 February 2020

(c) Some rights reserved / Creative Commons license 


\title{
Whose Tradition, Whose Identity? The politics of constructing "Nevruz" as intangible heritage in Turkey
}

\author{
Bahar Aykan
}

\section{Introduction}

1 UNESCO's heritage protection efforts have been extended from tangible to intangible cultural elements (oral traditions, social practices, festivals, rituals, performing arts, and so forth) following the adoption of the Convention for the Safeguarding of Intangible Cultural Heritage (hereafter ICH Convention) in 2003. This convention seeks to raise public awareness about the importance of sustaining the world's cultural diversity against the homogenizing effects of globalization. Stating intangible heritage as the "mainspring of cultural diversity" in its preamble, it calls upon States Parties to identify and safeguard intangible heritage located within their territories. While the ICH Convention only came into force in 2006, 161 states (as of November 2014) have already become a party to it. ${ }^{1}$ Furthermore, 317 cultural elements have been inscribed on its Representative and Urgent Safeguarding Lists so far. ${ }^{2}$ As such, the Convention is becoming more and more influential in shaping intangible heritage policies and practices in the contemporary world.

2 The ICH Convention, however, is not without its problems. A growing body of critical heritage literature has discussed how States Parties, which have a dominant role in its implementation and administration, often treat intangible heritage as a strategic tool for nation-building (e.g. Lixinski 2011; Logan 2010; Mountcastle 2010; Munjeri 2009). Stressing the strong connection between heritage and nationalism, this literature calls attention to States Parties' use of the Convention to legitimize and disseminate an official version of heritage for the promotion of national unity and identity. Such state 
dominance may also lead to the exclusion of alternative interpretations of heritage, especially the heritages of marginalized groups (national minorities, immigrants, indigenous people, etc.) and/or allow for the assertion of state ownership over their heritage, leading to the denial of their distinct pasts, identities, and cultures. This article discusses the case of Nevruz to explore these politico-nationalistic issues surrounding the making of intangible heritage.

Nevruz is the official Turkish name of a festival celebrated around the time of the vernal equinox, 21 March, in various Asian and Middle Eastern cultures to welcome the spring season. ${ }^{3}$ Even though there are many accounts as to the roots of the festival, a widely accepted version claims that it was originated as the New Year festival of Zoroastrians in Ancient Persia before Islam. The festival continued to be celebrated in Iran after the arrival of Islam and was adopted by other countries in the region (E. J. Brill's First Encyclopedia of Islam 1987: 888). While the festival is observed in various forms, picnics in open areas, preparation of special dishes, traditional folk music and dance performances, and visits to cemeteries, the elderly and neighbours are some activities that are typically held during the festival.

The festival's history in Turkey, however, shows how even such modest traditions might incorporate strong political meanings over time. Especially after the 1980s, this festival came to gain widespread political appeal among Turkey's Kurds as a powerful symbol of Kurdish identity and nationalism. "Newroz" (the Kurdish name of the festival) has played a salient role in mobilizing Kurds for national causes ever since, providing an occasion for them to demand recognition of their distinct identity. The political overtones of the festival, however, have made it a very controversial public celebration in Turkey.

5 One of the most problematic relations of the Turkish state has no doubt been with its Kurdish population. ${ }^{4}$ While Turkey has the largest Kurdish population in the world, estimated at between 12 and 15 million people (Bozarslan 2008: 334), Kurds are not officially recognized as a separate ethnic or minority group in Turkey. This has to do with the institutionalization of a single identity model since the establishment of the Turkish Republic in 1923 that has represented the nation as both ethnically Turkish and Sunni Muslim, with the exception of the recognition of Armenian, Greek Orthodox, and Jewish populations as non-Muslim minorities. This official denial of Kurdish identity has provoked constant opposition from Turkey's Kurds, who have repeatedly risen up against the state efforts to integrate them into Turkish national identity. Turkey's Kurdish issue took a more violent turn after the 1980s, when the PKK (Kurdistan Workers Party) launched a guerrilla war attacking both state and civilian targets in Turkey. Since then, the struggle between the PKK and Turkish armed forces has cost about 40,000 lives (Watts 2010: 22).

The PKK adopted the Newroz tradition in the mid-1980s and began to engage in violent attacks around 21 March especially in the predominantly Kurdish southeastern region of Turkey. It also called on Kurds to protest against the Turkish state on Newroz days. At first, the state responded by banning Newroz. The subsequent clashes that took place between the security forces and participants during the illegal Newroz events resulted in the death, injury, and arrest of many. Having failed to suppress the widespread celebration of Newroz, the state changed tactics in the 1990s. It adopted an official policy to dissociate Newroz from the Kurds. Through the promotion of "Nevruz" as a Turkish tradition, the state began to organize nationwide Nevruz activities (official 
ceremonies with the participation of high-ranking state officials, concerts, drawing and essay competitions for school children, and so forth). The adoption of the festival as a national holiday in several Central Asian Republics of the former Soviet Union further served to legitimize Turkey's new Nevruz policy (Yanık 2006: 292).

In 2009 Turkey, together with Azerbaijan, India, Iran, Kyrgyzstan, Pakistan, and Uzbekistan, successfully nominated the Nevruz festival for the ICH Convention's Representative List as the common heritage of these countries. When describing the celebration of the festival in Turkey, however, the nomination form submitted to UNESCO made no mention of Kurdish Newroz's customs and practices. ${ }^{5}$ In what follows, I discuss the heritagisation of Nevruz within the context of Turkey's Kurdish question and as an extension of its official Nevruz policy. I begin with exploring the complex intersections between heritage, politics and identity, and its instrumentality in nationbuilding. I subsequently give some background to the troubled history of Newroz celebrations in Turkey and the state attempts from the 1990s onwards to institutionalize Nevruz. Drawing on interviews with the state heritage authorities ${ }^{6}$ as well as the Nevruz heritage nomination form, I explore the ways in which its heritagisation serves to legitimize and promote Nevruz at both national and global levels as the UNESCO-approved, that is, the authentic and accurate version of the festival. Overall, the case of Nevruz is significant in illuminating not only the politiconationalist mechanisms through which intangible heritage is produced in Turkey, but also the increasingly critical role played by international heritage instruments in the legitimization of these mechanisms.

\section{Intangible Heritage and Nation-Building}

8 Cultural heritage is not something that is just out "there", free from human concerns and practices. As Llorenç Prats puts it, heritage is neither a "naturally occurring phenomenon, nor is it universal ... it is in fact a socio-cultural construction, born at a specific moment in history." (Prats 2009: 76). This construction almost inevitably involves the selective use of the past for the needs and purposes of present societies (Ashworth and Graham 2005: 7), and it is through this selective construction process that heritage's political function unfolds. Heritage making always entails complex negotiations for control between multiple interest groups over the process of determining which aspects of the past are to be identified, preserved, and managed as heritage, as well as the meanings to be assigned to them. Tunbridge and Ashworth (1996) explain this negotiation process with the concept of "dissonant heritage". According to them, cultural heritage is intrinsically dissonant; since various social groups tend to develop different versions of the past, conflicting meanings, interpretations, and uses often overlap in a single heritage tradition, object, or site.

9 The dissonance of heritage is strongly linked with the active role it plays in the construction, recreation, and legitimation of collective identities. A sense of a shared past that forms the basis of a collective identity manifests itself in particular cultural traditions, places, or objects. Anthropologist Annette B. Weiner (1992) has developed the concept of "inalienable possessions" to explain how the circulation of particular objects among generations play a vital role in the construction and recreation of collective identities, a process that makes these objects intrinsic to the identities of their possessors. In his essay "Identity as a Scarce Resource", Simon Harrison (1999) 
extends Weiner's argument from material objects to include an understanding of symbolic practices (dress styles, music, songs, sacred sites, religious expressions, festivals, ceremonies, and so forth). Harrison labels these symbolic practices as "identity symbols" and discusses the significance of collective claims over their possession and control for the manifestation and maintenance of distinct group identities. This, for him, reveals the exclusive, contested, and politically charged nature of these identity symbols; given that, identities rest on maintaining an exclusive relationship with symbolic practices, they thus have the power to prevent outsiders from reproducing these markers of identity (Harrison 1999: 243).

Even though Harrison does not specifically discuss cultural heritage as an identity symbol, critical heritage literature has long been claiming it as a vehicle for constructing a shared identity, belongingness, and unity as well as for manifesting difference and particularity. The process of identity formation is driven both by the politics of inclusion and exclusion: identity is a meaning ascribed both to similarity and difference, as Peralta and Anico remind us, "in order to identify with some, people also need to dis-identify with someone else" (Peralta and Anico 2009: 1). As an identity symbol, then, heritage can unite as well as it can divide (Silverman and Ruggles 2007: 3). Whereas it encourages unity and belonging among some people, it does so by excluding some others from its ownership. In the words of Tunbridge and Ashworth:

At its simplest, all heritage is someone's heritage and therefore logically not someone else's: the original meaning of an inheritance implies the existence of disinheritance and by extension any creation of heritage from the past disinherits someone completely or partially, actively or potentially (Tunbridge and Ashworth 1996: 21).

11 This politics of inheritance and disinheritance manifests itself very clearly in nationbuilding. Strengthening a sense of national identity and unity among diverse groups of people is fundamental to any nation-building project. Heritage serves as a powerful tool for nation-building in this respect. As Graham et al. have suggested, "imagining of an internal national homogeneity... draws inevitably upon a particular representation of heritage and a mythology of the past for its coherence and legitimacy" (Graham et al 2000: 56). Heritage encourages national identity and unity through a particular representation of the past that promotes a common history, shared memories, values, and traditions, in an effort to produce a national whole that transcends cultural, ethnic, and religious differences, or any other particularisms occurring within the nation. In a study based on a fieldwork she conducted among Hungarian folk revivalists, Mary N. Taylor discusses how the efforts to preserve traditional folk dance/music as Hungarian intangible heritage contributes to the country's nation-building process by boosting a sense of Hungarianness among urban citizens and Hungarian minorities in the neighbouring countries. As she explains, for three decades, the folk revival initiated by the táncház movement led to the flood of folk revivalists into the remote Hungarian villages in Romania in search for "masters" to teach them the "authentic" folk dance/ music in traditional settings. These efforts have been institutionalized following the 1990s as weeklong summer camps in these villages, where thousands of urban Hungarians learn to master folk dance/music as their "mother tongue" (Taylor 2009: 47). According to Taylor, by fostering a sense of national identity and unity among Hungarian citizens and Hungarian minorities in Romania, these efforts to preserve intangible heritage contribute to not only the reproduction of the nation but also the reconsideration of ethno-national boundaries (Taylor 2009: 49). 
12 National heritage, however, excludes as well as includes. According to Logan et al., the states promote national heritage as part of a strategy to strengthen a sense of shared national identity and to integrate minority groups into the national mainstream (Logan et al 2010: 10-11). In this respect, national heritage is deployed as a powerful political tool not only in constructing a homogenized national whole, but also in denying the distinctiveness of minority groups from it. In her study of Burma's heritage protection programs, Janette Philp discusses how the country's authoritarian military rule engages in heritage protection to achieve its own nation-building goals. According to Philp, these programs operate as a strong political tool in forcing Burma's ethnic and religious minorities to conform to a homogenized national identity that is both Buddhist and ethnically Burman (Philp 2010: 83). She discusses three different strategies adopted by the military rule to this end, all of which are aimed toward denying minority groups' own sense of history and identity: the promotion of an ethos of "unity in diversity" that allows these groups to express cultural diversity so long as it does not challenge national identity; the destruction of the heritage of minorities to deny their right to assert cultural particularity; and the assimilation of minorities into a national identity, wherein their heritage is redefined as national heritage (Philp 2010: 85).

While UNESCO has been at the forefront of cultural heritage issues especially following the adoption of the World Heritage Convention in $1972,{ }^{7}$ a particular concern has been expressed in critical heritage literature about the use of its heritage programs for the purposes of nation-building. States Parties play a dominant role in the implementation and administration of the UNESCO's heritage programs. While these programs operate on global, national, and local levels, since international law is made by nation-states, the national (i.e. state) level remains primary to their enactment (Blake 2009: 47).

The ICH Convention is no exception to this. It was, in fact, meant to depart from a topdown approach to heritage management by facilitating the participation of culture bearers in the decision-making process. Indeed, their vital role in the making of intangible heritage, and the centrality of this form of heritage to their shared sense of identity and belonging, is recognized in the texts and documents of the Convention (Blake 2009). It likewise develops a community-based approach in defining the scope of intangible heritage, stating in Article 2(1) that only the cultural elements identified by culture bearers (and not by the experts or state heritage authorities) as their shared heritage can be considered intangible heritage by UNESCO. Furthermore, Article 15 invites States Parties to secure the widest possible involvement of culture bearers in the management of their intangible heritage, and the criteria for the inscription on the intangible heritage lists asks States Parties to prepare nominations with their full participation.

15 Despite these measures, however, States Parties still remain the leading actors in the ICH Convention. The state heritage authorities make most of the crucial decisions regarding the identification and management of intangible heritage. In most cases, the Ministries of Culture or other relevant state institutions function as the executive bodies of the Convention at the national level. They decide on the cultural elements to be identified and proposed as intangible heritage to the Intangible Heritage Lists, as well as the meanings to be attributed to these elements. Furthermore, the Intergovernmental Committee to the Convention posits the definition of community as unnecessary, considering the one adopted by the state heritage authorities to be 
adequate in showing community participation in decision-making (Lixinski 2011: 85). In this respect, the decision of how to define the bearers of a cultural element and who, which groups or individuals, will be included and excluded from participation in the decision-making process also rests with state heritage authorities.

Such state sovereignty prevents the Convention from offering remedies for its misappropriation by States Parties (Lixinski 2011: 94), and this has serious repercussions for national minorities. It may come at the expense of the absence or underrepresentation of minority heritage within UNESCO's intangible heritage program (Alivizatou 2012: 41). More severely, playing into the hands of assimilationist states (Marrie 2009: 178), this program may serve to support the assertion of state ownership over minority heritage, leading to the denial of minority identities and cultural values. As such, the ICH Convention, like the World Heritage Convention, by enhancing instead of overcoming "nation-state-based power structures and nationalist agendas", operates as a tool for cultural domination (Askew 2010: 20).

Several scholars have already explored these complex politico-nationalistic issues surrounding UNESCO's intangible heritage program for instance, through an examination of the ways in which it aids ongoing Chinese state efforts to incorporate the Tibetan identity into the Chinese national identity (e.g. Lixinski 2011; Mountcastle 2010). Similarly, William Logan (2010) explores how the inscription of the Tay Nguyen minority's gong music into the UNESCO list by the Vietnamese government actually serves for integrating them into the mainstream. In a study on Balkan Romani musicians, Carol Silverman discusses how the exclusion of Roma cultural practices from Macedonia's UNESCO application to list the wedding festival of Galicnik village as the Masterpiece of the Oral and Intangible Heritage of Humanity contributes to the country's nation building goals. ${ }^{8}$ As she suggests, while these practices are an integral part of the Galicnik Wedding Festival, and the villagers are dependent on Roma musicians for their dance, ritual, and ceremonial music, "UNESCO application hardly mentions Roma and omits them in relation to the goals of affirming cultural identity" (Silverman 2012: 171). Nevruz provides yet another strong case for elaborating on the link between the state, nation-building, and intangible heritage. Before moving on to discuss the heritagisation process of the festival, however, I will first give some background to its troubled history in Turkey.

\section{Newroz versus Nevruz}

18 While historically Nevruz was a traditional celebration in Turkish culture, it was not adopted as an official festivity by the Turkish state until the 1990s (Demirer 2005: 146-147). Nevruz was celebrated widely as a public holiday in the Ottoman Empire (E. J. Brill's First Encyclopedia of Islam 1987: 888). It was, however, neither recognized as national heritage by the Turkish state, nor was it celebrated publicly in the early years of the Republic. In fact, prior to the adaption of Newroz by Kurds as a protest event in the late 1970s, it had only been referred to as an Iranian tradition in the mainstream newspapers (Yanık 2006: 287). An article published in daily Milliyet ${ }^{9}$ in 1953, for instance, described Nevruz as the "traditional and national festival of Iranians", when announcing the celebration to be held at the Iranian Embassy the following day. ${ }^{10}$ Nevruz events organized by Iranians in Turkey, telegrams sent by state authorities to Iranian consuls, and series of descriptive articles on the history and customs of Nevruz 
in Iran were reported by Milliyet for more than two decades. By the late 1970s articles about Newroz celebrations held by some Marxist Kurdish organizations began to appear on newspaper pages. In 1977, Milliyet briefly mentioned Kurdish demonstrations to be held against the Turkish state in Italy. ${ }^{11} \mathrm{~A}$ year later, it reported on the protests organized in Ankara on Newroz day, and on the slogans ("long live Kurdistan", "death to slavery, long live freedom") that had been written in Kurdish on Ankara University buildings under the pseudonym Kawa. ${ }^{12}$

Kurds have been celebrating Newroz for centuries as their New Year, Sersal (Gunes 2012: 77). One of the first texts that mentions Newroz is Shahnameh, written in the $11^{\text {th }}$ century by the Persian poet Ferdowsi, who cites it as the day Persian king Jamshid came to the throne (Hür 2012: § 3). Ahmad-i Khani's famous Kurdish epic poem Mem û Zîn (1690) also mentions its celebration by Kurds (Hür 2012: § 6). Newroz, however, neither was a politicized event, nor served as an identity symbol until its association with the ancient Kurdish legend of Kawa in the 1950s by the Kurdish nationalist movements in Iran and Iraq. ${ }^{13}$ The version of the legend now commonly accepted among Kurds narrates the story of Kawa the blacksmith, who leads a successful revolt against the oppressive Assyrian King Dehak, liberates the ancestors of Kurds from his tyranny and lights a bonfire on the top of a hill to let everyone know that Dehak has been killed. Kawa's defeat of Dehak brings spring back to the region after centuries. Today, all the Kurdish movements in the Middle East accept this legend as the common founding myth of Kurds and celebrate Newroz as a national day to honor Kawa (Bozarslan 2002: 843).

While Newroz celebrations, usually in the form of picnics in the countryside, persisted among Kurds in southeastern Turkey following the foundation of the Turkish Republic, these events were neither widespread nor charged with political meanings (Aydın 2005: 69-70). The first attempts to turn Newroz into a national event among Turkey's Kurds emerged in the late 1970s. Kurdish intellectuals and students that organized around Marxist organizations sought out distinguishing characteristics of Kurdishness, and to this end, following the example of Kurdish movements in Iran and Iraq that associate Newroz with the Kawa legend, they declared Newroz as a Kurdish national festival to commemorate the victory of Kawa (Aydın 2014: 76). Favoring the formation of an independent state, these organizations aimed to strengthen an awareness of a common Kurdish identity with historical claims and cultural and linguistic distinctiveness. It was during this period that many Kurdish journals and books were published about the origin and history of Kurds, the Kurdish language and Kurdish customs and traditions becoming the center of attention (Aydın 2014: 76). Newroz was resurrected as a myth of origin within this context, explaining the emergence of Kurds as a nation and providing a powerful means of claiming Kurdish difference (Gunes 2012: 77). Just as the day Kurds were emancipated from oppression and achieved their freedom, Newroz also presented a "myth of resistance" (Hirschler 2001: 154), symbolizing the Kurdish struggle for independence against the Turkish state. Although attempts by these Kurdish organizations were significant in the redefinition of Newroz as a Kurdish myth of origin and resistance, the actual revival of Newroz as a widespread mass phenomenon took place following its adoption by the PKK.

21 The PKK was founded in 1978 under the leadership of Abdullah Öcalan with the goal of establishing an independent Kurdish state in southeastern Turkey. It adopted Newroz as a symbol of resistance following the suicide of PKK prisoner Mazlum Doğan on 21 March 1982, who had hanged himself in protest against the conditions of Diyarbakır 
prison and was named the "contemporary Kawa" by the PKK (Aydın 2014: 78). When the PKK began a series of systematic armed actions against the Turkish state in 1984, the attacks were especially coordinated around the time of Newroz. During Newroz in 1986, for instance, 34 soldiers and civilians, and 12 PKK members died in clashes between the PKK and Turkish armed forces in southeastern Turkey. ${ }^{14}$ From the mid-1980s onwards, Newroz came to be at the forefront of attention in Turkey. The country was on "Nevruz alarm" every March; additional troops and security forces were allocated to the southeast, and the media and state authorities constantly warned the public against possible PKK attacks.

The PKK also used Newroz as a unifying national myth to heighten awareness of a distinct Kurdish identity and to engender national consciousness, calling on Kurds to publicly celebrate Newroz. These celebrations played a key role not only in the public manifestation of Kurdish identity, but also in mobilizing political support for the PKK. While the celebrations were banned by the state, many Kurds poured onto the streets shouting pro-Kurdish and pro-PKK slogans, dancing and singing Kurdish traditional songs and jumping over bonfires in commemoration of the victory of Kawa. Various Kurdish politicians and activists delivered speeches on the meaning of Newroz for Kurdish identity and culture. The celebrations often turned violent when the security forces attempted to disperse the crowds. Clashes with them led to the death, injury, and arrest of many Newroz participants. ${ }^{15}$

Unable to prevent the celebration of Newroz by banning it, the Turkish state adopted a different strategy in the 1990s, recognizing Nevruz as a Turkish spring holiday in order to dissociate the festival from the Kurdish identity and the national movement. ${ }^{16}$ To this end, the Turkish Ministry of Culture issued a notice on 21 March 1991, declaring Nevruz to be a tradition rooted in ancient Asian Turkish culture and requesting that provincial culture directories across Turkey organize annual official Nevruz celebrations from that year on. ${ }^{17}$ Following this notice, state institutions, the mainstream media, and various Turkish nationalist groups embarked upon an intensive campaign to prove the festival's Turkishness.

24 As Lerna K. Yanık points out, after the 1990s the Turkish state devoted considerable efforts toward justifying the adoption of Nevruz as a Turkish tradition by linking its origin to Central Asia, the overall objective being to de-emphasize Kurdish affiliation with Newroz and counterbalance Kurdish nationalism (Yanık 2006: 288). Hence the state officially adopted the claim promoted in some politically marginal nationalist circles that the origin of Nevruz was derived from the Turkish national myth of Ergenekon, which refers to the legendary homeland of pre-Islamic Turks in the isolated mountains of Central Asia. ${ }^{18}$ According to the legend, the few remaining Turks that had survived a fatal battle took refuge in Ergenekon. They were trapped in the region for centuries until they grew in numbers and were able to return to their homeland with the help of a blacksmith who melted an iron mountain and a grey wolf who showed them the passage out. Their escape from Ergenekon marked the arrival of spring. Since then, Turks have considered the first day of spring to be Nevruz, celebrating it as the day they left Ergenekon and gained their independence.

Meanwhile, following the collapse of the Soviet Union, the newly independent states of Azerbaijan, Kazakhstan, Kyrgyzstan, Uzbekistan, and Turkmenistan, -with whom the Turkish state assumes a common history and culture and are referred to as "Turkic Republics" (Heper and Criss 2009: 313) - adopted Nevruz as a national holiday. The 
widespread celebration of Nevruz in these countries were viewed by state elites not only as additional proof of the festival's Turkish/Turkic roots, but also as a means of establishing closer ties with them (Yanık 2006: 285-286). Various Nevruz events, therefore, were organized together with the Central Asian Republics from the 1990s onwards. The first event of this kind was held on 21 March 1993, when Turkey organized an international congress titled "Friendship, Fraternity and Collaboration among Turkish States and Communities" with the participation of Turkey's high ranking state and government officials and over eight hundred representatives from the Central Asian Republics and Turkish communities in Asia and the Balkans. ${ }^{19}$ In his speech during the event, the then Prime Minister Süleyman Demirel wished happy Nevruz to the entire "Turkish" world, naming Nevruz as the celebration of the Ergenekon legend surviving from one generation to the next. ${ }^{20}$ After watching a movie depicting the legend of Ergenekon, event participants forged iron on an anvil as a symbol of Turks' departure from the region. ${ }^{21}$ Two years later, Turkey organized the first "Nevruz feast" in Ankara with the collaboration of TURKSOY, the International Organization of Turkic Culture..$^{22}$ The event hosted the Culture Ministers of Azerbaijan, Bashkortostan, Kazakhstan, Kirgizstan, and Tatarstan, and included activities such as official parades and folk dance performances from guest countries. ${ }^{23}$ Since then joint Nevruz celebrations with the Central Asian Republics have become a tradition in Turkey.

The past two decades have also seen a growth in one-sided academic works supporting the official state view on Nevruz. A short essay titled "Nevruz in Turkish Culture" that appeared in the Turkish Review Quarterly Digest, a scholarly journal published by the Turkish Directorate General of Press and Information, stated as early as 1992 that,

The history of Nevruz is as old as Turkish history ... The beginning of Nevruz goes back to the Legend of Ergenekon ... 21 March, the day when winter ends and spring starts, and the Turks announced their independence is celebrated as a festival. Khazakhs, Kyrgyz, Turkmen, Uzbeks, and Tatars from Central Asia, and Anatolian, Azerbaijani and Balkan Turks continue the Nevruz tradition to the present day ... We can say that Nevruz is a truly unique Turkish tradition. (pp. 51-52, emph. added)

Since then, similar arguments have been made in a plethora of publications to justify Turkey's official Nevruz policy. A typical publication of this sort begins with the definition of Nevruz as a common traditional cultural value among Turks and goes on to prove this by evoking the Ergenekon myth and citing various historical texts on Turks. Many such publications also claim the Turkish origins of Nevruz, arguing that Iranians adopted the tradition from the Turkish tribes that had migrated from Central Asia (e.g. Bayat 2008; Kafkasyalı 2005). This discussion is usually followed by a list of Nevruz practices in various other "Turkish" or "Turkic" Republics and their similarities with Turkey's Nevruz tradition. Different names and practices attributed to Nevruz celebrations in various regions of Turkey are also cited at length and in detail but without mention of the Kurdish ones (e.g. Karaman 2008; Uca 2007). Moreover, the practices attributed to Newroz are often highlighted as being genuinely Turkish: jumping over a bonfire, for instance, is claimed as an ancient Turkish tradition signifying the purification of the body and mind (Özdemir 2006). The fact that the celebration of the festival was forbidden for a long time in Turkey is hardly ever mentioned in these works and if so only implicitly such as to state that, "the celebrations in Turkey were interrupted from time to time" (Bayat 2008: 148). The Kurdish version of the festival is only mentioned occasionally and as a distortion of the 
original Turkish tradition - again, without mentioning the words "Kurd" or "Newroz". Nebi Özdemir, for instance, argues that "Nevruz will be purified from all sorts of political and ideological distortions that we call 'cultural pollution' and will continue to be celebrated in its original meaning" (Özdemir 2006: 18).

The Turkish state had also begun to organize official festivities in the southeast following the 1990s, in an effort to disseminate the Nevruz tradition among Kurds. A typical celebration of this kind would be attended by high-ranking government and state officials (including military personnel) who gave messages of solidarity and peace in their speeches and performed what was officially considered to be "old Turkish Nevruz customs" such as jumping over a bonfire or forging iron on an anvil. Several measures were employed to encourage Kurdish participation. These state-sponsored events were widely publicized through national television, radio, posters, and flyers, and free gifts were given away. In 1994, for instance, security forces invited the people of Cizre, a small town in the southeast, to the official Nevruz celebrations during which event military and police officers made speeches warning participants against the PKK, assisted them in lighting bonfires, and distributed Turkish flags and chocolate to children..$^{24}$ At this event a high-ranking army officer stated that, "we celebrate Nevruz too, but under the Turkish flag". ${ }^{25}$ Big-budget and fancy spectacles were organized occasionally. The 1996 Nevruz celebration held in Iğdır (a small town on Turkey's eastern border) with the participation of the then Prime Minister Mesut Yllmaz, for example, involved concerts by famous singers, firework displays, and folk dance performances, and the event was streamed live on various TV channels. ${ }^{26}$

Despite all these efforts, however, Kurdish participation in these state-sponsored events remained quite low. Many Kurds chose rather to gather in alternative Newroz celebrations organized by pro-Kurdish parties. ${ }^{27}$ These celebrations were planned in various cities and towns across the country by the "Newroz Organization Committees" composed of pro-Kurdish party members and Kurdish activists. These committees were responsible for developing the Newroz program schedule, deciding on the activities to be held and people to be invited, and obtaining the official permits and approvals necessary for organizing public celebrations in Turkey. Newroz applications, however, were occasionally rejected by state authorities for security reasons or were subjected to serious restrictions as to how, when, and where the celebrations could be held.

State authorities implemented various measures for diminishing the participation to Newroz. Occasionally, when 21 March fell on a weekday, permission was denied for the celebration of Newroz on a weekend, or locations far from the city center and with no public transportation were assigned for the celebration site. Newroz participants had to go through ID checks and security procedures before entering the celebration areas, which were closed down by barricades and surrounded by security forces. Any symbols or actions that could be associated with the PKK and the Kurdish identity were banned. PKK and Kurdish flags, Öcalan's posters, banners in Kurdish, and accessories with the Kurdish tri-colors (yellow, green, and red) were prohibited in the celebration areas and seized by the police. The security forces interfered when the crowds shouted slogans in Kurdish, in favor of the PKK and Öcalan, or against the Turkish state. When state authorities did not issue a permit for the celebrations, thousands gathered in unauthorized ones. In 1999, for instance, 11,000 people participated in unauthorized Newroz celebrations throughout Turkey and 2,400 of them were taken into custody. ${ }^{28}$ 
Amidst these tightened restrictions and regulations, Newroz has become more and more popular among Turkey's Kurds as a symbol of identity, and its nationwide celebrations have drawn ever-increasing crowds of all ages and social backgrounds. Today, a typical Newroz celebration begins with the speeches of prominent Kurdish politicians and activists on the significance of Newroz for the Kurdish identity and national movement, criticizing the state's Kurdish policy and demanding the official recognition of Kurdish identity and cultural rights. The event goes on with the commemoration of those who lost their lives for the Kurdish struggle, deliverance of Öcalan's Newroz message to the crowds, and concerts of Kurdish music. The crowds participate by shouting slogans, waving Kurdish flags, jumping over bonfires, and singing and dancing to traditional Kurdish songs. The celebrations in Diyarbakır are especially significant not only because they attract the most crowds (whose numbers are given in millions), but also because they include weeklong Newroz themed events ranging from photography and art exhibitions, panels, conferences, and official receptions to concerts by famous Kurdish musicians. Foreign politicians, NGO and union representatives and political activists also participate widely in these celebrations. Nevertheless, Newroz still constitutes a major source of conflict between the Turkish state and its Kurdish population. ${ }^{29}$ At the same time, the state pursues its official Nevruz policy and expands its efforts to promote the festival as a Turkish tradition. The next section explores the heritagisation of Nevruz as part of these efforts, discussing the ways in which it serves as a powerful means for legitimizing and promoting Nevruz as the UNESCO-approved authentic version of the festival at both national and global levels.

\section{III: Intangible Heritage Making of Nevruz}

The initial incentive for Nevruz's UNESCO nomination came from Iran. In 2004, Iran called upon countries of the region to jointly nominate the festival for the Masterpieces of the Oral and Intangible Heritage of Humanity list, and to this end held a meeting in Tehran from $7^{\text {th }}$ to $10^{\text {th }}$ August with the participation of Afghanistan, Azerbaijan, India, Kazakhstan, Kyrgyzstan, Pakistan, Tajikistan, Turkey, and Uzbekistan, to prepare a joint nomination form (Samadi Rendi 2008: 110). The application was submitted to UNESCO in 2005, but the festival did not make the list due to the incompleteness of the form and the absence of coordination between the applicant countries. ${ }^{30}$ Following the ICH Convention's entrance into force, Azerbaijan, Iran, Kyrgyzstan, Pakistan, Tajikistan, Turkey, and Uzbekistan came together for another meeting in Tehran, $25^{\text {th }}$ to $27^{\text {th }}$ August 2008, to revise the nomination form and propose the festival for its inscription on the Convention's Representative List (Samadi Rendi 2008: 110-111). The nomination was successful and in the fourth session of the Intergovernmental Committee held in Abu Dhabi in 2009 the festival made the list as the common tradition of applicant countries.

While Newroz continues to be celebrated extensively among Kurds all over the Middle East and in Europe as a potent symbol of their common identity and history, the customs, values, and practices of Newroz were invisible in the heritagisation process. The festival's nomination form identified culture bearers of the festival as "all people of the States Parties concerned" and its geographic location was widely recognized as ranging from the Indian subcontinent, Central Asia and the Mediterranean to Southeast Europe (UNESCO 2009: 2). Nevertheless, whilst the form cites the various 
names that the festival is called in different countries (i.e., Novruz, Nowrouz, Nooruz, Navruz, Nauroz, and Nevruz), Newroz is not mentioned among them. The fact that the festival continues to be extensively celebrated by Kurds across Iran, Iraq, Syria, and Turkey, and is recognized as a national holiday by the Kurdistan Regional Government of Iraq, was also absent in the nomination form.

The nomination form is particularly illuminating for an understanding of how the heritagisation of the festival contributes to Turkey's official Nevruz policy. While it details the various names attributed to the festival in Turkey (i.e., Mart Dokuzu, Mart Bozumu, Sultan Nevruz, Mereke, Yılsırtı, Yeniyıl, Ergenekon Bayramı, Çiğdem Günü, and Yumurta Bayraml), Newroz is not named among them (UNESCO 2009: 2). The form also cites the different myths attributed to the festival in Indian, Iranian, and Central Asian mythologies and mentions the "famous Bozkurt myth" (another name for the Ergenekon legend) from Turkey (UNESCO 2009: 2), yet nowhere in the document is the legend of Kawa mentioned. Moreover, the nomination form also claims jumping over a bonfire, a custom strongly associated with Newroz, as a Turkish Nevruz tradition (UNESCO 2009: 3). Even the participation of high-ranking state officials in the celebrations is presented as a safeguarding measure to sustain Nevruz (UNESCO 2009: 6-7). In fact, the word "Kurd" is found only once throughout the whole document: "There are some fire rituals at the Eve of Nowrouz/... among some groups such as Kurds and Zoroastrians as well as in Turkey and the Central Asian countries" (UNESCO 2009: 3). This statement is particularly interesting because the very existence of Kurds in Turkey is not even acknowledged. In addition, referring to the state-sponsored Nevruz celebrations where the government and state officials jump over bonfires to perform "old Turkish customs", this statement is in line with Turkey's attempts to popularize and disseminate the traditions attributed to Newroz as essentially and genuinely Turkish.

It became apparent during my research that this exclusion of Newroz from the festival's heritagisation process was not accidental. Indeed, the description of Nevruz on the official website of the Turkish Ministry of Culture and Tourism (hereafter TMCT) clearly demonstrates how its attitude towards the festival has not significantly changed in the past three decades:

Although it is has been claimed that Nevruz was a Persian conception, it also appears in the Twelve Animal Turkish Calendars, and had been known to the Turks and celebrated by them for a very long time. The principle [sic] view of Nevruz is the celebration of independence. In other words that it marks the day of departure from Ergenekon. Hence, Nevruz has been accepted as the beginning of the New Year by Turks and has still been celebrating [sic] with festivals. Among the Turkish communities of Central Asia, the Azeris, Kazakhs, Khirghiz, Türkmens, Uzbeks and Uyghur Turks, the Anatolian Turks and the Balkan Turks have kept the Nevruz tradition alive up to the present day. ${ }^{31}$

In the interviews, the TMCT officials all agreed with the above quote, explaining how Turks in Central Asia, Anatolia, and the Balkans have held festivities for centuries to commemorate their escape from Ergenekon and to welcome the arrival of spring. In addition, by stressing the national character of the festival and emphasizing its widespread practice by "all the people of Turkey", any association of the festival with Kurdish identity and culture -and, occasionally without reference to the words " Newroz" or "Kurd" - was strictly rejected. Indeed, a recurring theme in the interviews was that while some "groups" in Turkey have attempted to monopolize Nevruz as their own tradition, it is never the exclusive property of any "locality", but rather the 
national heritage of the whole country. One of the TMCT officials, for instance, explained the factors underlying their decision to approve Iran's proposal and contribute to the nomination process:

There is a deep-rooted Nevruz tradition in Turkey; we thought it was significant to nominate a practice that reflects Turkey's whole national profile... Nevruz is a practice that does not belong to any locality or specific community in Turkey. All the people of Turkey are part of this tradition.

While the TMCT defines culture bearers of Nevruz as "all the people of Turkey", Kurds are paradoxically excluded from this definition. When specifically asked why the festival's nomination form never once mentions Newroz, respondents replied that its exclusion was not a political decision, but a purely technical one. I was told that the TMCT was concerned only with the cultural and artistic aspects of intangible heritage, its activities falling totally outside the domestic political agenda. In one instance the interview became quite tense when a TMCT officer refused to answer my questions about Newroz, stating that: "you should ask it to the politicians; our office deals only with cultural tasks and not with political projects!"

Other respondents, however, entered into long explanations as to why Newroz is excluded from the heritage making of the festival. For them, this exclusion lies not in the fact that Newroz is celebrated by Kurds per se, but rather that its celebration does not conform to the "authentic" meaning and function of the festival. I was told that Nevruz is unique in that it had survived without losing its original form for centuries in various cultures from Asia to the Balkans and is celebrated as a spring holiday symbolizing the revival of nature and promoting values of unity, solidarity, peace, and tolerance. While Turkey's official Nevruz celebrations were claimed to be fully consistent with this authentic tradition, Newroz was seen as deviating from it. Respondents expressed the view that Kurds attempted to politicize an otherwise politically neutral spring festival and highlighted the ways in which the Kurdish version "doesn't follow the original tradition," "doesn't have the proper format," or else Kurds "ascribe inaccurate meanings" to the festival. While it goes without saying that Turkey's official Nevruz activities are no less "political" than Newroz celebrations, the former was referred as the "unpoliticized" and "authentic" form conforming to the purely cultural experience of the festival. Overall, the TMCT officials emphasized that they were not against the celebration of the festival by Kurds, but if they were to celebrate it, they should do so in its authentic form. Hence, Kurds were invited once more to celebrate Nevruz instead of Newroz, but this time to respect its UNESCOapproved authentic tradition. This view is well summarized by a TMCT official:

I am not at liberty to express my thoughts due to my position, but let me say that we are not claiming Nevruz merely as the cultural heritage of Turks. It is the cultural heritage of all the Middle Eastern and Central Asian people. It symbolizes the arrival of the spring season; its symbolic meaning is unity and solidarity. The UNESCO declaration proves this. We do not say that Kurds should not celebrate Nevruz, but they should respect its tradition. The UNESCO process shows that fake ideological and political meanings assigned to the festival are meant to fade away.

UNESCO's decision to inscribe the festival on the Representative List was often mentioned during the interviews as proof of Nevruz's authentic value. Government and state officials have also made similar arguments on Nevruz days following its heritage listing. For instance, in his speech broadcast live on various TV channels from the official Nevruz celebrations in Ankara, 2011, the then State Minister Faruk Çelik said 
that UNESCO's listing of Nevruz not only endorsed its authentic value, but also made it clear that "it should be a duty of each Turkish citizen to celebrate Nevruz in its authentic form, and not to permit its abuse by some exploiters." ${ }^{32}$

UNESCO, however, does not look for authenticity when inscribing cultural elements on the intangible heritage lists. Nor is it in the spirit of the ICH Convention to approve a certain version of an element as its authentic or original form. As Sophia Labadi points out, this move away from the notion of authenticity marks a significant shift from the World Heritage Convention, which recognizes authenticity as one of the key selection criteria for the inscription on the world heritage lists (Labadi 2013: 132). ${ }^{33}$ Article 2(1) of the ICH Convention defines intangible heritage broadly as:

... the practices, representations, expressions, knowledge, skills - as well as the instruments, objects, artefacts and cultural spaces associated therewith - that communities, groups and, in some cases, individuals recognize as part of their cultural heritage. This intangible cultural heritage, transmitted from generation to generation, is constantly recreated by communities and groups in response to their environment, their interaction with nature and their history, and provides them with a sense of identity and continuity, thus promoting respect for cultural diversity and human creativity.

41 Within this definition, questions concerning the authenticity, ownership, and origin of intangible heritage are irrelevant. According to Chiara Bortolotto, such a conceptualization of heritage is one of the most "daringly innovative" propositions of UNESCO, reflecting a significant shift in its definition of culture from one that is a "system of values profoundly rooted in the past and in land, and shared by homogeneous groups", to one that sees culture as a "dynamic process of contingent social construction that plays itself out on local, national, and global scales" (Bortolotto 2010: 108). Indeed, instead of considering intangible heritage as a fixed or static construct, the Convention views it as an active living culture, placing emphasis on its transmission from generation to generation and its constant recreation by culture bearers. It also recognizes that intangible heritage may change through time, or because people migrate, mix, and learn from each other, it may spread over to other parts of the world and be adopted by different cultural groups. Moreover, according to this definition any practice, knowledge, or skill that is rooted in the cultural traditions of people, and provides them with a sense of continuity and shared identity, can be considered intangible heritage. In this respect, an intangible heritage element can take on various forms, meanings, and uses across different cultural contexts, and these diverse versions are not hierarchically arranged with respect to one another.

Such an inclusive and holistic understanding of intangible heritage, however, is not always reflected on the ground. National interpretations of UNESCO's heritage programs might differ greatly from their original terms of reference, as it is not uncommon that these programs are used or abused by States Parties for political ends unrelated to heritage protection (Bortolotto 2010: 108). The ICH Convention rejects the idea of the exclusive ownership of intangible heritage and refrains from evaluating cultural elements in terms of their authenticity and originality. Nevertheless, nationalistic understandings still dominate the intangible heritage field. For instance, when a State Party registers a cultural element to the intangible heritage lists, it usually assumes itself to be officially approved by UNESCO as its authentic owner. This may generate international controversies over the origin and ownership of this element, especially when it is found within the territory of more than one country. I 
discussed these controversies elsewhere through Turkey's inscription of Karagöz shadow theatre and the ceremonial keşkek dish on the Representative List to claim them as authentically Turkish and to exclude Greece and Armenia (respectively) from their ownership (Aykan 2013b).

The case of Nevruz is interesting in that, this time an element's multinational inscription is taken as proof of the authenticity of its state-sponsored version, i.e. this version's conformity with the original meaning and function of the festival as observed in various other cultures. At the same time, Nevruz's UNESCO listing serves as a basis for the rejection of Newroz as the inauthentic version of the festival. In other words, the discourse of authenticity is invoked this time for domestic political or nationalist ends, both to delegitimize the heritage of a minority group and to justify the state-sponsored version as the UNESCO-approved authentic tradition.

There are, in fact, no obstacles against Newroz's heritage listing according to the rules of the Convention. As one of the most significant public manifestations of Kurdish culture providing a "sense of identity and continuity" and attracting millions of Kurds every year, Newroz celebrations qualify for an intangible heritage listing - and may be more so than the state-sponsored Nevruz celebrations, which despite efforts to disseminate the tradition more widely has not been embraced at the popular level. However, stateless Kurds, as ethnic minorities divided between several countries, cannot be represented in UNESCO's state-centered heritage system, and thus do not have the opportunity to nominate Newroz for the intangible heritage lists.

Unlike general opinion, the ICH Convention is not only about approving the universal value of some cultural elements through a prestigious global institution. By inscribing these elements to the UNESCO lists States Parties also commit to their safeguarding. During the interviews the dissemination and popularization of the "authentic" Nevruz tradition across Turkey is mentioned as fundamental for its safeguarding. As one of the TMCT officials explained:

Culture is a dynamic phenomenon, and in today's conditions we cannot safeguard Nevruz by encouraging people to have picnics on the countryside; our aim is to disseminate and popularize the genuine Nevruz spirit through formal and informal education and awareness-raising projects.

Another official stated that the Ministry's ultimate aim was to "stop organizing official Nevruz events after ensuring that the masses could celebrate it without our support." The respondents often brought up the fact that official Nevruz events did not achieve mass participation and that state and government authorities usually outnumbered the general public at them. Interestingly though, neither the troubled history of the festival in Turkey, Kurdish claims over it, nor the recent advent of official Nevruz events were mentioned as contributory factors when discussing its lack of popularity. Instead, Nevruz is presented as a tradition that has been forgotten gradually due to modernization and social change. According to a TMCT official:

Historically, Turks were one of the civilizations that celebrated Nevruz most vividly. It is one of the traditional Turkish values that fell into oblivion due to the process of modernization. This was not a conscious politics. [Emph. added]

47 As mentioned in the previous sections, for more than three decades and prior to its heritage inscription, various state-sponsored activities had already been organized throughout Turkey to popularize and disseminate Nevruz. These Nevruz-themed activities have been manifold, including but not limited to, marches, puppet and javelin 
shows, art exhibitions, Mehter Band performances, sports competitions, lotteries, concerts, and folk dance shows (Aydın 2014: 79). There have also been initiatives to disseminate the Nevruz tradition among younger generations. Since 2002, Turkish Nevruz customs have been taught in public schools as part of the curriculum, and it has been celebrated with weeklong activities and events. Furthermore, the Ministry of National Education organizes annual nationwide "Nevruz in Turkish culture" painting, essay, and poetry competitions for the school children sending a notice to all public schools each year to encourage widespread student participation.

I was told in the interviews that the heritage listing of the festival had generated additional interest and funding from the Turkish government for the promotion of Nevruz at both national and international levels. The government currently sponsors weeklong Nevruz activities (seminars, panels, sport competitions, concerts, art and photography exhibitions, and so forth) as a package program to be delivered in all cities and towns throughout Turkey. The TMCT prepares information pamphlets and brochures on the importance of Nevruz in Turkish culture and Nevruz souvenirs for children (Turkish flags, Nevruz themed coloring and comic books, t-shirts, balloons, etc.) to be distributed in these nation-wide events. Additionally, the Turkish national channel TRT1 airs a daylong "Nevruz special program" on 21 March giving information on the history of the Turkish Nevruz tradition, the meanings attributed to the festival by ancient Turks, and the Nevruz customs and practices observed in Turkey and the Central Asian countries. The official Nevruz celebration held in Ankara is broadcast live as part of this program, which also presents special coverage of the celebrations from Central Asian countries as well as official celebrations in various cities and towns throughout Turkey.

The heritage listing of Nevruz has also initiated some efforts to promote and popularize it on an international scale. Following Kyrgyzstan's proposal in 2010 the UN General Assembly recognized March $21^{\text {st }}$ as "International Nevruz Day". From that year on, TURKSOY, together with the TMCT, has begun to organize annual Nevruz celebrations throughout the world, with the participation of artists performing folk dances associated with the festival from Turkey and Central Asian Republics. The first of these events were held at the UNESCO headquarters in Paris and the Council of Europe's headquarters in Strasbourg. In 2011 in addition to the Nevruz show held at the UN headquarters in New York, the TMCT and TURKSOY organized a four-day-long Nevruz program featuring panels, conferences, concerts, and receptions in New York, Boston, and Washington, DC. Similar Nevruz events were also held in Germany, Luxemburg, and England. Being more than just an occasion to introduce the Nevruz tradition to an international audience, these events also served as a platform for the justification of Turkey's official Nevruz policy at the international level.

\section{Conclusion}

The case of Nevruz provides a concrete illustration of the politico-nationalistic uses of UNESCO's intangible heritage program, especially for those countries, such as Turkey, struggling with diversity issues. Despite its original intention to depart from a topdown heritage management approach, this program gives States Parties a "near-total control over the meanings and uses" of intangible heritage (Lixinski 2013: 129). This dominant role of the state in decision-making results in the use of the ICH Convention 
to promote a shared national heritage for the purposes of nation-building; serving, on the one hand, to foster a unified national identity and culture, and on the other hand, to reject the distinctiveness of minority identity and culture from the larger national whole.

The preceding discussion has explored the heritagisation process of Nevruz as an extension of Turkey's official Nevruz policy. Through the exclusion of Kurdish customs and values and the representation of Nevruz as Turkey's national heritage, this process functions as a tool for delegitimizing Newroz as the politically charged and inauthentic version of the festival. At the same time, it works to validate Nevruz as the UNESCOapproved authentic tradition, providing a powerful means of legitimizing Turkey's official Nevruz policy at both national and international levels. The ICH Convention aims to promote bottom-up approach to heritage management, but its policies and discourses are framed at the national level (Askew 2010: 38). As far as intangible heritage is considered within the wider framework of the state, nation-building, and minority politics this is a major limitation. Overall, UNESCO's intangible heritage program aids the efforts of States Parties to strengthen their control over the heritage of national minorities or other marginalized groups. It is a politics that justifies the nationalization of marginalized heritage in the name of preserving it.

\section{BIBLIOGRAPHY}

Alivizatou, Marilena (2012) Intangible Heritage and the Museum: New Perspectives on Cultural Preservation, Walnut Creek, Left Coast Press.

Ashworth, G. J.; Graham, Brian (2005) "Senses of Place, Senses of Time and Heritage", in

Ashworth, G. J.; Graham, Brian (eds.), Senses of Place: Senses of Time, Hants, Ashgate, pp. 3-14.

Askew, Marc (2010) "The magic list of global status: UNESCO, World Heritage and the agendas of states", in Labadi, Sophia; Long, Colin (eds.), Heritage and Globalisation, New York, Routledge, pp. 19-44.

Aydın, Delal (2005) Mobilizing the Kurds in Turkey: Newroz as a myth. Master's Thesis, Middle East Technical University, URL: http://etd.lib.metu.edu.tr/upload/12606923/index.pdf

Aydın, Delal (2014) “Mobilising the Kurds in Turkey: Newroz as a myth", in Gunes, Cengiz; Zeydanlığlu, Welat (eds.), The Kurdish Question in Turkey: New Perspectives on Violence, Representation, and Reconciliation, New York, Routledge, pp. 68-88.

Aykan, Bahar (2012) “UNESCO ve Kültürel Mirasın Milliyeti”, in Yelsalı Parmaksız, Pınar Melis (ed.), Neye Yarar Hatıralar? Bellek ve Siyaset Çalışmaları, Ankara, Phoenix, pp. 303-337.

Aykan, Bahar (2013a) "How Participatory is Participatory Heritage Management? The Politics of Safeguarding the Alevi Semah Ritual as Intangible Heritage", International Journal of Cultural Property 20(4), pp. 381-405. URI: http://dx.doi.org/10.1017/S0940739113000180

Aykan, Bahar (2013b) "Sharing Heritage? The Controversy over the Multinational Inscriptions on UNESCO's Intangible Heritage Lists”, in Lira, Sergio; Amoeda, Rogerio; Pinheiro, Cristina (eds.) 
Sharing Cultures 2013 - Proceedings of the $3^{\text {rd }}$ International Conference on Intangible Heritage, Aveiro, Greenlines Institute, pp. 41-50.

Blake, Janet (2009) “UNESCO's 2003 Convention on Intangible Cultural Heritage: the implications of community involvement in safeguarding”, in Smith, Laurajane; Akagawa, Natsuko (eds.), Intangible Heritage, New York, Routledge, pp. 45-73.

Bayat, Fuzuli (2008) “Sosyo-Kültürel ve Sosyo-Ekonomik Bağlamda Yengi Kün (Nevruz): Mitolojik Olgudan Mitolojik Kurguya”, Gaziantep Üniversitesi Sosyal Bilimler Dergisi 7 (1), pp. 139-148. URL: http://jssarchive.gantep.edu.tr/index.php/sbd/article/download/29/28

Bortolotto, Chiara (2010) "Globalising intangible cultural heritage? Between international arenas and local appropriations", in Labadi, Sophia; Long, Colin (eds.), Heritage and Globalization, New York, Routledge, pp. 97-114.

Bozarslan, Hamit (2002) “Kürd Milliyetçiliği ve Kürd Hareketi (1898-2000)”, in Bora, Tanıl (ed.), Milliyetçilik, Istanbul, İletişim, pp. 841-870.

Bozarslan, Hamit (2008) "Kurds and the Turkish state", in Kasaba, Resat (ed.), The Cambridge History of Turkey, Vol. 4: Turkey in the Modern World, Cambridge, Cambridge University Press, pp. 333-356.

Demirer, Yücel (2005) "Rite of Passage as a Communal Classroom: The Pedagogical Recycling of Traditional New Year Celebrations in Turkey", in Ewing, Thomas E. (ed.), Revolution and Pedagogy: Interdisciplinary and Transnational Perspectives on Educational Foundations, New York, Palgrave Macmillan, pp. 133-162.

E. J. Brill's First Encyclopedia of Islam, 1913-1936 (1987), Leiden, E. J. Brill.

Engelhardt, Richard (2002) “UNESCO Presentation: Regional Perspectives", Promotion of the "Proclamation of Masterpieces of the Oral and Intangible Heritage of Humanity", Final Report of 2002 Regional Workshop for Cultural Personnel in Asia and the Pacific, Tokyo, Japan, 12-16 March, 2002. Tokyo, UNESCO.

Graham, Brian; Ashworth, G. J.; Tunbridge, J. E. (2000) A Geography of Heritage Power, Culture and Economy, London, Hodder Arnold.

Gunes, Cengiz (2012) The Kurdish National Movement in Turkey: From Protest to Resistance, New York, Routledge.

Gunter, Michael M. (2004) "The Kurdish Question in Perspective”, World Affairs 166 (4), pp. 197-205. URL: http://www.jstor.org/stable/20672696

Harrison, Simon (1999) “Identity as a Scarce Resource”, Social Anthropology 7 (3), pp. 239-251. URI: http://dx.doi.org/10.1111/j.1469-8676.1999.tb00193.x

Heper, Metin; Criss, Nur Bilge (2009) Historical Dictionary of Turkey, Lanham, Scarecrow Press.

Hirschler, Konrad (2001) "Defining the Nation: Kurdish Historiography in Turkey in the 1990s", Middle Eastern Studies 37 (3), pp. 145-166. URL: http://www.jstor.org/stable/4284177

Hür, Ayşe (2012) “Geleneğin icadı: Newroz ve Nevruz”, Taraf, URL: http://www.taraf.com.tr/ yazilar/ayse-hur/gelenegin-icadi-newroz-ve-nevruz/20449/

Kafkasyalı, Ali (2005) “Türk Dünyasında Nevruz Geleneğine Toplu Bakış”, Atatürk Üniversitesi Sosyal Bilimler Enstitüsü Dergisi 6 (2), pp. 149-172. URL: http://e-dergi.atauni.edu.tr/ataunisosbil/article/ download/1020000224/1020000219 
Karaman, Ramazan (2008) “Anadolu'da Nevruz Kutlamaları”, Hitit Üniversitesi Ilahiyat Fakültesi Dergisi 7 (13), pp. 129-145. URL: http://www.arastirmax.com/system/files/dergiler/36454/ makaleler/13/1/arastrmx_36454_13_pp_129-145.pdf

Labadi, Sophia (2010) "World Heritage, authenticity and post-authenticity: international and national perspectives", in Labadi, Sophia; Long, Colin (eds.), Heritage and Globalization, New York, Routledge, pp. 66-84.

Labadi, Sophia (2013) UNESCO, Cultural Heritage, and Outstanding Universal Value: Value-based Analyses of the World Heritage and Intangible Cultural Heritage Conventions, Maryland, AltaMira Press.

Lixinski, Lucas (2011) “Selecting Heritage: The Interplay of Art, Politics and Identity”, European Journal of International Law 22 (1), pp. 81-100.

Lixinski, Lucas (2013) Intangible Cultural Heritage in International Law, Oxford, Oxford University Press. URI: http://dx.doi.org/10.1093/ejil/chr001

Logan, William (2010) "Protecting the Tay Nguyen gongs: conflicting rights in Vietnam's central plateau”, in Langfield, Michele; Logan, William; Craith, Máiréad Nic (eds.) Cultural Diversity, Heritage and Human Rights, New York, Routledge, pp.189-207.

Logan, William; Langfield, Michele; Craith, Máiréad Nic (2010) “Intersecting concepts and practices”, in Langfield, Michele; Logan, William; Craith, Máiréad Nic (eds.) Cultural Diversity, Heritage and Human Rights, New York, Routledge, pp. 3-20.

Marrie, Henrietta (2009) “The UNESCO Convention for the Safeguarding of the Intangible Cultural Heritage and the protection and maintenance of the intangible cultural heritage of indigenous peoples", in Smith, Laurajane; Akagawa, Natsuko (eds.), Intangible Heritage, New York, Routledge, pp. 169-192.

McDowall, David (2010) A modern history of the Kurds, London, I.B. Tauris.

Mountcastle, Amy (2010) "Safeguarding Intangible Cultural Heritage and the Inevitability of Loss: A Tibetan Example”, Studia ethnologica Croatica 22, pp. 339-59. URL: http://hrcak.srce.hr/file/ 93296

Munjeri, Dawson (2009) "Following the length and breadth of the roots: some dimensions of intangible heritage", in Smith, Laurajane; Akagawa, Natsuko (eds.), Intangible Heritage, New York, Routledge, pp.131-150.

“Nevruz in Turkish Culture” (1992) Turkish Review Quarterly Digest 6(30), pp. 51-52.

Özdemir, Nebi (2006) "Yeni/lenmek ve Nevruz”, Milli Folklor 18(69), pp. 15-27. URL: http:// www.millifolklor.com/tr/sayfalar/69/69.pdf\#page=15

Peralta, Elsa; Anico, Marta (2009) "Introduction”, in Peralta, Elsa; Anico, Marta (eds.), Heritage and Identity: Engagement and Demission in the Contemporary World, New York: Routledge, pp. 1-11.

Philp, Janette (2010) “The political appropriation of Burma's cultural heritage and its implications for human rights", in Langfield, Michele; Logan, William; Craith, Máiréad Nic (eds.) Cultural Diversity, Heritage and Human Rights, New York, Routledge, pp. 83-100.

Prats, Llorenç (2009) "Heritage According to Scale”, in Peralta, Elsa; Anico, Marta (eds.) Heritage and Identity: Engagement and Demission in the Contemporary World, New York, Routledge, pp. 76-90.

Samadi Rendi, Leila (2008) "Final Report of Second Coordinating Meeting of the Countries Celebrating Nowrouz Preparation of Nowrouz Multi-National File”, Milli Folklor 20 (79), pp. 110-111. URL: http://www.millifolklor.com/tr/sayfalar/79/18_.pdf 
Silverman, Carol (2012) Romani Routes: Cultural Politics and Balkan Music in Diaspora, Oxford, Oxford University Press.

Silverman, Helaine; Ruggles, Fairchild D (2007) “Cultural Heritage and Human Rights”, in Silverman Helaine; Ruggles, Fairchild D. (eds.) Cultural Heritage and Human Rights, New York: Springer, pp. 3-22.

Taylor, Mary N. (2009) “Intangible Heritage governance, cultural diversity, ethno-nationalism”, Focaal 55, pp. 41-58.

Tejel, Jordi (2009) Syria's Kurds: History, Politics and Society, New York, Routledge.

Tunbridge, J. E.; Ashworth G. J. (1996) Dissonant heritage: the management of the past as a resource in conflict, Chichester, J. Wiley.

Uca, Alaattin (2007) “Türk Toplumunda Nevruz-I”, A. Ü. Türkiyat Araştırmaları Enstitüsü Dergisi 32 , pp. 137-170.

UNESCO (2009) “Novruz, Nowrouz, Nooruz, Navruz, Nauroz, Nevruz Nomination Form”, pp.1-14, URL: http://www.unesco.org/culture/ich/index.php?RL=00282

Van Bruinessen, Martin (2000) "Transnational aspects of the Kurdish question" Working paper, Robert Schuman Centre for Advanced Studies, European University Institute Florence, pp. 1-30, URL: http://let.uu.nl/ martin.vanbruinessen/personal/publications/transnational_Kurds.htm Yanık, Lerna K. (2006) “"Nevruz” or "Newroz”? Deconstructing the "Invention” of a Contested Tradition in Contemporary Turkey”, Middle Eastern Studies 42 (2), pp. 285-302. URI: http:// dx.doi.org/10.1080/00263200500417710

Watts, Nicole F. (2004) “Turkey’s Tentative Opening to Kurdishness”, Middle East Research and Information Project, URL: http://ns2.merip.org/mero/mero061404

Watts, Nicole F. (2006) “Activists in Office: Pro-Kurdish Contentious Politics in Turkey", Ethnopolitics 5 (2), pp. 125-144. URI: http://dx.doi.org/10.1080/17449050600655235

Watts, Nicole F. (2010) Activists in Office: Kurdish Politics and Protests in Turkey, Seattle, University of Washington Press.

Weiner, Annette B. (1992) Inalienable possessions: the paradox of keeping-while-giving, Berkeley, University of California Press.

Yanık, Lerna K. (2006) “'Nevruz' or 'Newroz'? deconstructing the 'invention' of a contested tradition in contemporary Turkey” Middle Eastern Studies 42(2) pp.285-302 URI: http://dx.doi.org/ $10.1080 / 00263200500417710$

\section{NOTES}

1. Turkey is one of these countries, having ratified the Convention in 2006. In addition to Nevruz, Turkey has ten other cultural elements that have been inscribed on the Representative List of the Intangible Cultural Heritage of Humanity so far: Arts of the Meddah, public story-tellers (2008); Mevlevi Sema Ceremony (2008); Așıklık (minstrelsy) tradition (2009), Karagöz Shadow Theatre (2009); Alevi-Bektaşi Semah Ritual (2010); Kırkpınar Oil Wrestling Festival (2010); Traditional Sohbet Meetings (2010), Ceremonial Keşkek Tradition (2011); Mesir Macunu Festival (2012); and Turkish Coffee Culture and Tradition (2013). For more on the politics of intangible heritage in Turkey and its particular consequences on the heritage of marginalized groups, see Aykan (2012) and Aykan (2013a). 
2. The ICH Convention has two lists. The principal list is called the Representative List of the Intangible Cultural Heritage of Humanity. This list includes cultural elements that are representative of the world's cultural diversity, whose viability is not at direct risk of disappearance. The second list is called the List of Intangible Cultural Heritage in Need of Urgent Safeguarding, which includes cultural elements that are in direct risk of disappearance and in need of immediate safeguarding.

3. "Nevruz" refers to the festival's officially used spelling in Turkey, whereas "Newroz" indicates the Kurdish spelling of the festival, commonly used not only by Turkey's Kurds, but also by Kurds in Iran, Iraq, and Syria. As will be discussed more extensively below, while the festival's nomination form for the UNESCO intangible heritage listing cites its alternative spellings in various Middle Eastern and Asian cultures (i.e., Novruz, Nowrouz, Nooruz, Navruz, Nauroz, and Nevruz), the Kurdish spelling of the festival is not mentioned among them.

4. There is no consensus in the literature regarding the origin of the Kurds. In fact, as Bozarslan (2008: 334) states, arguing toward one exclusive and homogeneous Kurdish identity proves difficult due to great varieties within the population in terms of language, religion, and geography. Kurds are Kurmanji, Surani, Zaza, or Gurani speakers, and the majority of them (approximately 75\%) subscribe to Sunni Islam, while Alevi, Shia, and Yazidi Kurds are distinctive minorities (McDowall 2010: 9-11). Until the early 20th century, the majority of Kurds lived in the mountain villages that fell on the border of the Ottoman and Persian Empires. Although no precise figures for the Kurdish population exist, their overall numbers are estimated at approximately 25 to 28 million (Gunter 2004: 197). While many Kurds have moved to big cities or those seeking asylum have migrated to Europe, the majority still live in the area that today corresponds to the borders of Turkey, Syria, Iran, and Iraq, and there are also some enclaves of Kurds living in Armenia and Azerbaijan (Gunter 2004: 197).

5. This article examines the heritagisation of Nevruz within the context of Turkey's Kurdish question. The Newroz traditions of Kurds in Iraq, Iran, and Syria, the heritagisation processes of the festival in other countries, and the different traditions relating to the festival as it is practiced throughout Turkey by Alevis, Turkmens, or other groups, lie beyond the limits of this study.

6. The following discussion partially draws on five face-to-face and semi-structured interviews with the executives and personnel of the Turkish Ministry of Culture and Tourism Intangible Heritage Department, the administrative body of the ICH Convention in Turkey. This department is in charge of developing Turkey's national intangible heritage inventory, selecting the cultural elements to be nominated for the UNESCO's intangible heritage lists, preparing their nomination forms, and ensuring the safeguarding of the listed elements. The interviews were carried out between July 2010 and July 2011 and varied in length between thirty minutes and two hours. I have withheld the names of the respondents because they requested that their names be removed from the publication.

7. The World Heritage Convention has been ratified by 191 countries and has 779 listed cultural properties as of November 2014. It is the second most ratified international convention after the Convention on the Rights of the Child (Engelhardt 2002: 29).

8. UNESCO's Masterpieces program came into force in 2001 to raise global awareness for the protection of intangible heritage while the ICH Convention was being drafted. The nominations to the Masterpieces List were evaluated by an international jury of intangible heritage experts and representatives from relevant NGOs selected by UNESCO. The program was finalized when the ICH Convention came into force in 2006 and ninety items recorded in the Masterpieces List were incorporated into the ICH Convention's Representative list in 2008.

9. Founded in 1950, Milliyet has been one of the major mainstream daily newspapers in Turkey with a high national circulation.

10. Milliyet, "Iranlılar Yarın Nevruzu kutlayacaklar," 20 March 1953. 
11. Milliyet, "Kürtlerin Protesto Mitingi," 17 March 1977.

12. Milliyet, "SBF Duvarlarına Kürtçe Sloganlar Yazıldı," 22 March 1978.

13. The incorporation of the legend of Kawa into the Newroz tradition was neither initiated by, nor is peculiar to, Turkey's Kurds, but rather learnt from the Kurdish nationalist movements in Iran and Iraq. While Iraq's Kurds were first to adopt Newroz as a national holiday in the 1950s (Van Bruinessen 2000: 9), there are also accounts as to the efforts of Iran's Kurdistan Democratic Party to relate Kawa legend with Newroz during the same period (Aksoy in Aydin 2014: 76).

14. Milliyet, "16 er, 18 sivil öldü," 25 March 1986.

15. The deadliest Newroz occurred in 1992 when at least 70 participants died in clashes with the security forces (Watts 2004: 5).

16. It is interesting to note that the Syrian government employed a similar tactic from the 1980s onwards and recognized Newroz as a national celebration in an attempt to suppress its popularity among the Syrian Kurds (Tejel 2009: 136).

17. Milliyet, "Nevruz'a Resmi Kutlama," 21 March 1991.

18. The first attempts to associate Nevruz with the Ergenekon legend can be traced back to the Committee of Union and Progress (CUP) government in the late Ottoman era. The CUP declared Nevruz as a Turkish national festival and held official Nevruz celebrations as "Ergenekon day" in the years of 1914 and 1915 (Karaman 2008: 132). There are also some records of minor Nevruz celebrations after the end of CUP rule that were organized by nationalist associations during the War of Independence (Karaman 2008: 132).

19. Milliyet, “Antalya'da Türk Kurultayı,” 22 March 1993.

20. Milliyet, “Antalya'da Türk Kurultay1," 22 March 1993.

21. Milliyet, “Antalya'da Türk Kurultay1," 22 March 1993.

22. TURKSOY was established in 1993 with the aim of strengthening cultural relations among "Turkish language speaking countries" and promoting their cultural and artistic activities at the international level (TURKSOY, "Hakkımızda," URL: http://www.turksoy.org.tr/tr/turksoy/ hakkimizda). Since then, the organization has been working together with the Turkish government to organize Nevruz events, dealing especially with the planning of activities as well as the invitation and hosting of folk dance, music, and theatre groups from participant Central Asian countries. TURKSOY's headquarters is in Ankara and its member states are Azerbaijan, Kazakhstan, Kyrgyzstan, Uzbekistan, Turkey, Turkmenistan, Altai Republic, Bashkortostan, Gagauzia (Moldova), Khakassia, the Turkish Republic of Northern Cyprus, the Republic of Sakha (Yakutia), Tatarstan, and Tyva.

23. Milliyet, "Özgürce Kutladılar," 22 March 1995.

24. Milliyet, "Resmi Nevruz Kutlamas1," 22 March 1994.

25. Milliyet, "Resmi Nevruz Kutlamas1," 22 March 1994.

26. Milliyet, “Başbakan Nevruz'u Iğdır'da Kutlayacak', 19 March 1996.

27. In her article Activists in Office: Pro-Kurdish Contentious Politics in Turkey, Nicole F. Watts argues that participation of pro-Kurdish parties in Turkish electoral politics from the 1990s onwards provided the Kurdish national movement with the possibility of expressing itself through nonviolent means. Kurdish participation in the Turkish political system, however, has not been without restriction. Various successive pro-Kurdish parties, the People's Labour Party (1990-1993), the Democracy Party (1993-1994), and the People's Democracy Party (1994-2003) were closed down by the constitutional court for promoting Kurdish nationalism or due to their connection with the PKK (Watts 2006: 134). The Democratic Society Party (2005-2009) was also closed down by the constitutional court. Currently, Turkey's major pro-Kurdish party is called the Peace and Democracy Party, which succeeded the Democratic Society Party in 2009.

28. Milliyet, “2 bin 400 Gözaltı," 23 March 1999.

29. Serious clashes between security forces and Newroz participants occurred in 2012, when the Ministry of Interior did not permit the celebration of Newroz on a Sunday. The pro-Kurdish 
Peace and Democracy Party called for large demonstrations and thousands of Kurds poured out onto the streets across Turkey to celebrate Newroz despite the Ministry's decision. The security forces tried to disperse the protestors with tear gas and water cannons. According to a report published by the Human Rights Association, the events resulted in the death of one person, while 178 people were injured, and 1014 people were taken into custody, 206 of whom were arrested Bianet, "Newroz Kutlamalarında 1014 Gözaltı", 02 April 2012, URL: http://bianet.org/bianet/ ifade-ozgurlugu/137364-newroz-kutlamalarinda-1014-gozalti

30. Payvand News, "Masterpieces of the Intangible Heritage Proclaimed by UNESCO", 12 December 2005, URL: http://www.payvand.com/news/05/dec/1185.html 12/23/05

31. "Nevruz Celebrations in Turkey and in Central Asia", URL: http://www.kultur.gov.tr/EN, 35076/nevruz-celebrations-in-turkey-and-in-central-asia.html

32. Personal notes from my participation in the official Nevruz celebrations held in Ankara Genç lik Park on 21 March 2011.

33. Authenticity is one of the most controversial subjects in the heritage field. UNESCO's use of it to identify world heritage has been viewed by critical heritage scholars and non-Western heritage professionals as a reflection of the organization's Western/Eurocentric interpretation of heritage. The World Heritage Convention considered authenticity in four areas until recently, indicating that authenticity of any property lies in its original material, design, workmanship, and setting (Labadi 2010: 69). This conceptualization, however, proved to be limited in its application to non-Western properties. UNESCO addressed the question of authenticity at the 1994 Nara Conference held in Japan. The Conference participants adopted the Nara Document on Authenticity, which took a cultural relativist view to the identification of world heritage. Arguing that values attributed to heritage properties may differ from culture to culture and even within the same culture, paragraph 11 of the document stated that heritage properties should be understood within their cultural context and their authenticity should not be evaluated through fixed criteria. The document also argued for a broader understanding of the concept of authenticity, stating in paragraph 13 that authenticity of a property not only lies in its design, material, workmanship, and setting but also in its use, function, traditions, techniques, spirit, and feeling. The World Heritage Committee, however, did not modify the Operational Guidelines according to the Nara document until its 2005 revision (Labadi 2010: 71).

\section{ABSTRACTS}

This article problematizes the tendency of States Parties to use UNESCO's 2003 Convention for the Safeguarding of Intangible Cultural Heritage as a political tool for nation-building. Having overall control and authority over the administration and implementation of this Convention, States Parties often use it to promote an official version of intangible heritage to foster national identity and unity. Such state dominance may in some cases result in strengthening the state's control over the heritage of minority groups and contribute to the appropriation of their heritage as national heritage, becoming a means to reject their identities and cultures. I discuss these politico-nationalistic issues surrounding the 2003 Convention through the case of "Nevruz", a very controversial festival in Turkey. 
INDEX

Keywords: UNESCO, ICH Convention, Intangible Heritage, nation-building, Nevruz, Newroz, Turkey

\section{AUTHOR}

\section{BAHAR AYKAN}

Department of Sociology

Marmara University, Istanbul, Turkey 